\title{
ANALISIS DIFFERENTIAL COST DAN OPPORTUNITY COST DALAM PENGAMBILAN KEPUTUSAN MEMBELI ATAU MEMPRODUKSI SENDIRI PADA INDUSTRI RUMAH PANGGUNG WOLOAN
}

\section{ANALYSIS OF DIFFERENTIAL COST AND OPPORTUNITY COST IN THE DECISION TO PURCHASE OR PRODUCE THEMSELVE ON STAGE INDUSTRI RUMAH PANGGUNG WOLOAN}

\author{
Oleh: \\ Romeo Fersi Mongdong ${ }^{1}$ \\ Jenny Morasa ${ }^{2}$ \\ Heince Wokas ${ }^{3}$ \\ ${ }^{1}$ Fakultas Ekonomi dan Bisnis Jurusan Akuntansi \\ Universitas Sam Ratulangi \\ email: ${ }^{1}$ Mongdongromeo@yahoo.co.id ${ }^{1}$
}

\begin{abstract}
Abstrak:Dunia usaha dewasa ini ditandai dengan semakin ketatnya persaingan diantara perusahaan yang ada.Persaingan ini terjadi di dalam semua sektor perekonomian baik industri, perdagangan dan jasa. Salah satu keputusan yang harus di ambil dalam perencanaan pada setiap alternatif adalah membeli atau memproduksi sendiri suatu komponenbahan baku. Biaya Diferensial mempunyai hubungan dengan biaya peluang, dimana biaya diferensial adalah biaya yang timbul akibat adanya keputusan tertentu sedangkan biaya peluang adalah biaya yang dikeluarkan ketika memilih suatu keputusan.Tujuan penelitian ini untuk menganalisis biaya diferensial dan biaya peluang dalam pengambilan keputusan membeli atau memproduksi sendiri pada Industri Rumah Panggung Woloan. Metode analisis yang digunakan adalah deskriptif kuantitatif.Hasil analisis biaya diferensial menunjukkan keputusan yang tepat yang dapat diambil oleh manajemen perusahaan yaitu memproduksi sendiri karena mendapatkan laba diferensial yang lebih tinggi, dibandingkan membeli dari luar. Sedangkan dari biaya peluang membeli bahan baku dari luar lebih menguntungkan, dengan demikian memproduksi sendiri menjadi lebih mahal. Sebaiknya pimpinan Industri Rumah Panggung Woloan memproduksi sendiri Kayu dari luar karena akan lebih menguntungkan, dibandingkan dengan mengambil kayu yang di tanam sendiri.
\end{abstract}

Kata Kunci :biaya diferensial, biaya peluang, membeli atau memproduksi sendiri

\begin{abstract}
The business world today is characterized by increasing competition among existing companies. Competition occurs in all sectors of the economy both industry, trade, and services. One of the decisions that must be taken in planning at every alternative is to buy or produce itself a component of raw materials. Differential cost are related to the opportunity cost, which is the differential cost incurred costs as a result of certain decisions while the opportunity cost is the cost incurred when choosing a decision. The purpose of this study to analyze the differential costs and opportunity costs in the decision to buy or produce their own on Industri Rumah Panggung Woloan. The analytical method used is descreptive quantitative. Result of the differential cost analysis showed that the right decisions can be taken by the management company the manufactures its own because getting a hihgter differential gain, compared to buying from outside. While the opportunity cost of the buying raw materials from outside is more profitable, thus producing itself becomes more expensive. Should the leadership Industri Rumah Panggung Woloan produce their own wood from the outside becauseit would be more adventageous, compared to taking wood there are kept alone.
\end{abstract}

Keywords: differential cost, opportunity cost, to buy or produce its own 


\section{PENDAHULUAN}

\section{Latar Belakang}

Dunia usaha dewasa ini ditandai dengan semakin ketatnya persaingan diantara perusahaan - perusahaan yang ada.Persaingan ini terjadi di dalam semua sektor perekonomian baik industri, perdagangan maupun jasa.Perkembangan ilmu pengetahuan dan teknologi telah membuat perubahan ke arah kompetisi yang semakin ketat.Persaingan bisnis dalam perebutan pasar telah menuntut unit usaha untuk memiliki kelebihan dalam unit usahanya baik dari segi efisiensi, kualitas produk, teknologi dan tentu saja kualitas sumber daya manusianya

Perusahaan pada umumnya bertujuan untuk meningkatkan laba, agar mampu mempertahankan kelangsungan hidupnya serta memperluas usahanya.Analisis diferensial mengukur berapa besar pendapatan dan biaya diferensial yang terjadi jika manajemen memilih suatu alternatif.Apabila laba diferensial akibat pemilihan alternatif membeli lebih besar dari pada laba diferensial akibat pemilihan alternatif memproduksi sendiri, maka manajemen harus mengambil keputusan membeli. Dengan diharapkan laba perusahaan akan meningkat karena biaya produksi lebih rendah.

Perkembangan industri produk makanan di Indonesia terus menunjukkan peningkatan bahkan mampu bersaing dipasar nasional. Perusahaan harus berusaha mencari cara bagaimana untuk dapat menghasilkan produk dengan biaya serendah mungkin dan tentu dengan kualitas yang sebaik mungkin agar dapat meningkatkan laba perusahaan. Pihak manajemen harus mengambil keputusan yang tepat dari berbagai alternatif - alternatif yang ada untuk mencapai tujuan tersebut.Pembuatan keputusan ini harus dilakukan oleh manajemen dengan dukungan berbagai informasi yang memadai agar dapat menghasilkan keputusan yang baik untuk menghasilkan keputusan yang baik untuk menghasilkan suatu produk yang berkualitas dan dapat meningkatkan laba perusahaan.

Salah satu keputusan yang perlu di ambil dalam perencanaan pada setiap alternatif adalah membeli atau memproduksi sendiri suatu komponen bahan baku. Keputusan membuat atau memproduksi sendiri adalah keputusan manajemen menyangkut apakah sebuah komponen harus diproduksi sendiri ataukah dibeli dari pemasok lain. Karena berbagai macam alasan, sebuah perusahaan dapat memproduksi sebuah produk atau suatu jasa lebih murah dari pada perusahaan lain (Simamora, 2012:235). Biaya diferensial mempunyai hubungan dengan biaya peluang, dimana biaya diferensial adalah biaya yang timbul akibat adanya keputusan tertentu sedangkan biaya peluang adalah biaya yang dikeluarkan ketika memilih suatu keputusan jadi dalam perusahaan apabila biaya diferensialnya mengambil keputusan memproduksi sendiri maka biaya peluang yaitu membeli dari luar bahan baku.

Industri Rumah Panggung Woloan adalah produksi rumah kayu yang bergerak di bidang usaha produksi rumah panggung,di mana dalam menjalankan aktivitas usahanya, perusahaan memerlukan bahan baku yang diperoleh dari luar perusahaan sehingga dapat dilihat dari kelancaran proses produksi dalam perusahaan, maka perusahaan harus berusaha menyediakan sesuai dengan kebutuhan.

\section{Tujuan Penelitian}

Adapun tujuan penelitian ini adalah untuk menganalisis biaya diferensial dan biaya peluang dalam pengambilan keputusan membeli atau memproduksi sendiri pada Industri rumah panggung woloan. Dimana industri rumah panggung woloan melihat mana yang paling menguntungkan diantara membeli kayu dari luar atau memproduksi sendiri.

\section{TINJAUAN PUSTAKA}

\section{Konsep Akuntansi}

Horgren (2009:4), akuntansi adalah sistem akuntansi yang mengukur aktivitas bisnis, memproses data menjadi laporan, dan mengkomunikasikan hasilnya kepada para pengambil keputusan. Selanjutnya menurut Arfan (2009:2), akuntansi dapat di pandang sebagai suatu proses atau kegiatan yang meliputi proses pengidentifikasian, pengukuran, pencatatan, pengklasifikasian, penguraian, penggabungan, pengiktisaran dan 
penyajian data keuangan yang terjadi sebagai akibat dari kegiatan operasi suatu unit organisasi. Dari pengertian diatas, dapat disimpulkan bahwa akuntansi adalah sebagai alat ukur yang memberikan informasi umumnya dalam ukuran uang mengenai suatu badan ekonomi yang berguna bagi pihak-pihak intern maupun ekstern perusahaan dalam pengambilan keputusan

\section{Akuntansi Manajemen}

Akuntansi manajemen adalah proses pengidentifikasian, pengukuran, penghimpunan, penganalisisan, penyusunan, penafsiran, dan pengkomunikasian informasi keuangan yang digunakan oleh manajemen untuk merencanakan, mengevaluasi, dan mengendalikan kegiatan usaha di dalam sebuah organisasi, serta untuk memastikan penggunaan dan akuntabilitas sumber daya yang tepat (Simamora, 2012:13). Dalam konten ini informasi keuangan meliputi semua informasi, keuangan maupun nonkeuangan, yang dibutuhkan untuk menginterpretasikan dampak peristiwa ekonomik atau konsekuensi keputusan bisnis .Selanjutnya menurut (Arfan, 2009:3) menyatakan akuntansi manajemen merupakan akuntansi yang berhubungan dengan penyediaan spesialisasi informasi internal bagi para manajer yang secara langsung bertanggung jawab dan mengendalikan operasi bisnis.Dan menurut (Krismiaji, 2011:1) juga mengatakan akuntansi manajemen adalah salah satu cabang ilmu akuntansi yang menghasilkan informasi untuk manajemen atau pihak intern perusahaan.Pengguna utama informasi akuntansi manajemen adalah para manajer, yang bertugas merencanakan kegiatan, menerapkan rencana, dan mengarahkan serta mengendalikan kegiatan organisasi tersebut atau berjalan sesuai rencana. Dari pengertian di atas, dapat disimpulkan bahwa akuntansi manajemen adalah proses memasok informasi yang relevan kepada manajer dan tenaga kerja,baik informasi keuangan maupun non keuangan, untuk pengambilan keputusan, pengalokasian sumber daya, dan pemonitoran, pengevaluasian, dan pemberian imbalan terhadap kinerja.

\section{Biaya}

Kautsar (2013:20) mendifinisikan biaya adalah suatu nilai tukar, pengeluaran-pengeluaran yang dilakukan untuk menjamin perolehan manfaat.Widilestariningtyas (2012:25) menyatakan biaya adalah nilai tukar, pengeluaran, pengorbanan untuk memperoleh manfaat lebih baik.Sedangkan menurut Krismiaji, (2011:17) menyatakan biaya adalah kas atau ekuivalen yang dikorbankan untuk membeli barang atau jasa yang diharapkan akan memberikan manfaat bagi perusahaan saat sekarang atau untuk periode mendatang. Istilah biaya dalam akuntansi, didefinisikan sebagai pengorbanan yang dilakukan untuk mendapatkan barang atau jasa, pengorbanan mungkin diukur dalam kas, aktiva yang ditransfer, jasa yang diberikan dan lain-lain, hal ini diperkuat oleh pendapat (Witjaksono, 2006:6) mengemukakan bahwa Biaya adalah suatu pengorbanan sumber daya untuk mencapai suatu tujuan tertentu. Akuntansi biaya adalah ilmu, dalam pengertian bahwa akuntansi biaya merupakan hal yang dapat dipelajari dan tentu saja telah memenuhi kaidah-kaidah tertentu untuk dapat diakui sebagai suatu disiplin ilmu; anatara lain logis, dan telah diterima serta dipraktekkan oleh banyak orang. (Witjaksono, 2006:2).

\section{Biaya Diferensial (Differential Cost)}

Supomo (2012 : 11) pengertian akuntansi adalah adalah sebagai berikut: "Akuntansi diferensial merupakan informasi akuntansi yang menyajikan informasi mengenai taksiran pendapatan, biaya dan atau aktiva yang berbeda jika suatu tindakan tertentu dipilih, dibandingkan dengan alternatif tindakan yang lain"

\section{Biaya Peluang (Opportunity Cost)}

Opportunity cost ini penting sebagai bahan pertimbangan bagi penggunaan sumber daya, misalnya suatu gedung milik perusahaan dapat disewakan 10 juta per tahun, bila gedung tersebut digunakan sendiri oleh perusahaan maka opportunity costnya adalah 10 juta. Menurut Darsono (2005 : 22) Opportunity Cost(biaya kesempatan) yaitu manfaat yang dikorbankan pada saat memilih satu diantara beberapa alternaitf kesempatan untuk memperoleh benefit laba atau keuntungan. Seiring dengan peluang/kesempatan, maka akan berpengaruh terhadap biaya pengeluaran. Biaya Pengeluaran dapat diartikan pengeluaran berupa uang tunai untuk dibayarkan selama periode tertentu.Pengeluaran dapat juga diartikan sebagai suatu nilai yang dibayarkan atau dikonsumsi. 


\section{Keputusan Membeli atau Memproduksi Sendiri}

Manajemen sering dihadapkan pada persoalan yang berkaitan erat dengan penggunaan bahan produksi. Di satu pihak perusahaan mempunyai fasilitas untuk memproduksi suku cadang tertentu, di pihak lain perusahaan dapat membeli suku cadang tersebut dari perusahaan lain. Jika fasilitas perusahaan untuk memproduksi suku cadang tersebut telah mencapai kapasitas penuh, maka untuk memenuhi kebutuhan proses produksi karena meningkatnya volume penjualan perusahaan, barangkali dapat dibenarkan jika perusahaan memutuskan untuk membeli kekurangan suku cadang yang diperlukan dari perusahaan lain. Akan tetapi dalam hal kapasitas perusahaan perusahaan untuk memproduksi suku cadang masih cukup tersedia, maka keputusan untuk membeli suku cadang dari luar harus mempertimbangkan biaya diferensial dan kemungkinan fasilitas perusahaan yang menganggur.Pada dasarnya pengambilan keputusan yang menyangkut beberapa alternatif harus mempertimbangkan aspek kualitatif dan aspek kuantitatif dari pemilihan alternatif tersebut.Aspek kualitatif adalah segi yang tidak dapat diukur dari satuan uang dalam pengambilan keputusan.Misalnya dalam hal perusahaan memutuskan untuk membeli suku cadang dari luar sementara kapasitas perusahaan menganggur.

\section{Penelitian Terdahulu}

Dewinta (2014) Melakukan penelitian berjudul Penerapan biaya diferensial dalam pengambilan keputusan membeli atau meproduksi sendiri pada RM. Pangsit Tompaso.Tujuan penelitian ini adalah untuk mengetahui penerapan biaya diferensial dalam pengambilan keputusan membeli atau meproduksi sendiri.Penelitian ini dilakukan dengan metode deskriptif.Hasil penelitian ini menunjukan keputusan yang tepat yang dapat diambil manajemen adalah meproduksi sendiri.Perbedaan dalam penelitian ini yaitu objek penelitian yang berbeda juga bukan hanya menganalisis biaya diferensial tetapi juga menganalisis biaya peluang atau kesempatan.

Iqbal (2013) melakukan penelitian yang berjudul pengaruh biaya diferensial terhadap proses pengambilan keputusan manajemen memproduksi sendiri atau membeli produk studi pada PT. Fintex. Tujuan penelitian ini untuk mengetahui pengaruh biaya diferensial terhadap pengambilan keputusan membeli atau meproduksi sendiri produk pada PT. Fintex. Penelitian ini menggunakan metode deskriptif dan hasil penelitian ini menunjukkan bahwa biaya diferensial sangat mempengaruhi suatu pengambilan keputusan.

\section{METODE PENELITIAN}

\section{Jenis Penelitian}

Jenis penelitian ini menggunakan metode penilitian deskriptif kuantitatif, yaitu metode yang menganalisis masalah dengan cara mendeskripsikannya pada data-data yang sudah ada, berupa tabel perhitungan biaya produksi untuk mengetahui perbandingan biaya produksi kayu yang dapat memberikan gambaran maupun uraian jelas mengenai analisis biaya diferensial dan biaya peluang dalam pengambilan keputusan membeli atau memproduksi sendiri kayu pada Industri Rumah Panggung Woloan.

\section{Jenis Data Dan Sumber Data}

\section{Jenis Data}

Menurut Kuncoro (2004:25), data berdasarkan jenis data terbagi dua,yaitu sebagai berikut

1. Data kuantitatif yaitu data yang berbentuk angka atau bilangan. Sesuai dengan bentuknya, data kuantitatif dapat diolah atau dianalisis menggunakan teknik perhitungan matematik atau statistika. Data kuantitatif dalam penelitian ini yaitu data biaya produksi dalam usaha tersebut.

2. Data kualitatif yaitu data yang berbentuk kata-kata, bukan dalam bentuk angka. Data kualitatif diperoleh melalui berbagai macam wawancara,analisis dokumen, atau observasi. Data kualitatif yang akan diambil seperti wawancara mengenai proses pengambilan keputusan membeli atau memproduksi sendiri. 


\section{Sumber Data}

Indrianto dan Supomo (2009:146) menyatakan bahwa sumber data penelitian terdiri atas 2, yaitu :

1. Data primer

Data primer adalah sumber data penelitian yang diperoleh secara langsung dari sumber asli

2. Data Sekunder

Data sekunder adalah sumber data penelitian yang diperoleh peneliti secara tidak langsung melalui media perantara

\section{Teknik Pengumpulan Data}

Penulis menggunakan beberapa teknik pengumpulan dat sebagai berikut :

1. Penelitian Awal

Suatu penelitian dimana hal ini dilakukan untuk memperoleh gambaran mengenai objek penelitian sehingga dapat mengetahui dan menentukan permasalahan yang dihadapi

2. Penelitian Lapangan (Field Search)

Suatu penelitian dimana data diperoleh melalui penelitian yang langsung dilakukan pada perusahaan yang bersangkutan dimana diambil sebagian besar diperoleh dengan teknik pengumpulan data sebagai berikut :

a) Observasi

Metode Pengumpulan data yang dilakukan dengan cara terjun langsung ke objek yang diteliti dengan mengamati apa yang menjadi sasaran dalam pengambilan data sesuai dengan apa yang diperlukan

b) Wawancara

Metode pengumpulan data dengan mengadakan tanya jawab langsung dengan pihak-pihak yang terkait guna memperoleh keterangan tentang hal-hal yang menjadi objek penelitian dan mengharapkan memperoleh gambaran objek yang diteliti.

\section{Metode Analisis Data}

Metode analisis data yang digunakan dalam penelitian ini yaitu metode analisis deskriptif.Metode ini merupakan suatu metode yang bertujuan menguraikan, membandingkan, memberikan gambaran perusahaan, dan menerangkan suatu data kemudian dianalisa sehingga dapat membuat kesimpulan sesuai dengan informasi dan data yang telah ada. Penelitian ini juga menggunakan analisa. Kuantitatif, dan analisis kuantitatif yang digunakan yaitu informasi akuntansi diferensial karena menghitung biaya produksi perusahaan,dengan cara membandingkan biaya produksi pada saat memproduksi sendiri kayu tersebut dengan harga kayu yang ditawarkan oleh pemasok.

\section{Definisi Operasional}

Penelitian ini berjudul Analisis Biaya Diferensial dan Opportunity cost dalam pengambilan keputusan membeli atau memproduksi sendiri pada Industri Rumah Panggung Woloan. Dimana akan dijelaskan maksud dari penelitian yang diteliti :

1. Biaya diferensial merupakan perbedaanbiaya yang timbul akibat adanya keputusan tertentu.Misalnya manajemen melakukan penambahan volume produksi manajemen memilih alternatif proses produksi. Jika biaya diferensial itu disebabkan karena adanya penambahan volume produksi maka perbedaan itu dapat disebut dengan biaya incremental(Incremental Cost) atau biaya marginal(Marginal Cost)

2. Biaya peluang adalah manfaat yang dikorbankan pada saat memilih satu diantara beberapa alternaitf kesempatan untuk memperoleh benefit laba atau keuntungan. Misalnya, suatu gedung milik perusahaan dapat disewakan 10 juta per tahun, bila gedung tersebut digunakan sendiri oleh perusahaan maka biaya peluangnya adalah 10 juta.

3. Keputusan membeli atau memproduksi sendiri merupakan suatu keadaan dimana manajemen diperhadapkan dengan pertimbangan untuk penawaran harga dari pemasok luar untuk suatu komponen produk yang berada dibawah biaya produksi sendiri komponen tersebut. 


\section{HASIL PENELITIAN DAN PEMBAHASAN}

\section{Hasil Penelitian}

\section{Gambaran Umum Perusahaan}

Industri Rumah Panggung Woloan adalah tempat memproduksi rumah panggung yang sudah terkenal diberbagai daerah Tomohon dan sekitarnya.Industri Rumah Panggung Woloan ini dibuka sejak 01 Maret 2010 dan masih beroperasi sampai saat ini.Industri Rumah Panggung Woloan ini berlokasi di Woloan Utara, kecamatan Tomohon Barat.Usaha Produksi rumah panggung ini adalah usaha keluarga. Awalnya Industri Rumah ini hanya memproduksi rumah panggung berukuran biasa-biasa saja baik 1 tingkat maupun 2 tingkat, tetapi seiring berjalannya waktu dengan persaingan dalam dunia usaha produksi rumah panggung yang semakin ketat, maka Industri Rumah Panggung Woloan dengan kreatifitasnya menciptakan ide lainnya seperti gazebo depan rumah. Industri rumah panggung woloan sebagai salah satu industri produksi ruma panggung yang terkenal dan memiliki banyak peminat. Industri rumah panggung woloan ini terkenal dengan produksi rumah kayu 1 tingkat, 2 tingkat, setiap rumah yang di produksi harganya beragam, tergantung peminat yang menyukai bentuk dan kualitas rumah, harga yang ditawarkan mulai dari Rp. 40.000 .000 hingga ratusan juta. Seiring berjalannya waktu dengan persaingan dalam usaha perindustrian yang semakin ketat, maka Industri Rumah Panggung Woloan ini dengan kreatifitasnya menciptakan Produksi Gazebo.

Tabel 1. Biaya Bahan Baku Kayu Periode 2014

\begin{tabular}{|c|c|c|c|c|}
\hline Keterangan & Jumlah Unit & Harga & r Unit & Total \\
\hline $\begin{array}{l}\text { Bahan Baku } \\
\text { Langsung }\end{array}$ & Kayu & 984 & Rp.600.000 & Rp. 590.400 .000 \\
\hline Biaya Mesin & $\begin{array}{l}\text { Senso Kayu } \\
\text { Skap Kayu } \\
\text { Mesin Bor Duduk }\end{array}$ & $\begin{array}{l}2 \\
2 \\
2\end{array}$ & $\begin{array}{l}\text { Rp.5.000.000 } \\
\text { Rp.4.200.000 } \\
\text { Rp.1.800.000 }\end{array}$ & $\begin{array}{l}\text { Rp. } 10.000 .000 \\
\text { Rp. } 8.400 .000 \\
\text { Rp. } 3.600 .000\end{array}$ \\
\hline \multirow{3}{*}{$\begin{array}{l}\text { Biaya Tenaga } \\
\text { Kerja langsung } \\
\text { Biaya Overhead } \\
\text { Pabrik }\end{array}$} & & & & Rp. 945.000 .000 \\
\hline & $\begin{array}{l}\text { Penyusutan } \\
\text { Peralatan }\end{array}$ & & & Rp.59.318.000 \\
\hline & $\begin{array}{l}\text { Biaya } \\
\text { Listrik }\end{array}$ & & & Rp. 12.480 .000 \\
\hline TOTAL & & & & Rp. 1.629.198.000 \\
\hline
\end{tabular}

Sumber :Industri Rumah Panggung Woloan

Tabel 1 ini menjelaskan biaya untuk mengokah bahan baku kayu berjumlah Rp. 1.629.198.000 dimana biaya-biaya produksi berupa biaya bahan baku langsung sebesar Rp. 590.400.000, Biaya mesin sebesar Rp. 22.000.000, Biaya tenaga kerja langsung Rp. 945.000.000, Biaya overhead pabrik Rp. 71.798.000.

Hasil Penelitian Ditinjau dari Biaya Diferensial

Tabel 2. Perbandingan Biaya Diferensial Membeli atau Memproduksi sendiri Periode 2014

Keterangan Kayu Siap Pakai Kayu Setengah Jadi

Biaya Bahan Baku Langsung

Rp. 590.400 .000

Biaya Mesin

Rp. 71.789 .000 
Biaya Tenaga Kerja

Langsung

Biaya Overhead Pabrik

Harga Beli

(984 x Rp. 800.000)

Total Biaya Diferensial
Rp. 945.000 .000

Rp. $\quad 59.318 .000$

Rp. 787.200 .000

Rp. 787.200 .000

Rp. 1.666 .507 .000

\begin{abstract}
Penghematan Biaya
Rp. 879.307.000

Sumber : Hasil data olahan 2014

Perbandingan biaya diferensial yang telah disajikan pada tabel 2, diketahui bahwa ada beberapa biaya diferensial yang muncul saat perusahaan memilih alternatif untuk membuat sendiri yaitu, biaya bahan baku langsung, biaya mesin, biaya tenaga kerja langsung, dan biaya overhead pabrik. Total biaya yang akan dikeluarkan oleh pihak perusahaan jika memutuskan untuk memproduksi sendiri kayu setiap tahunnya yaitu sejumlah Rp. 1.666.507.000. Sedangkan biaya yang akan dikeluarkan oleh perusahaan jika memilih alternatif untuk membeli kayu yang siap pakai dari luar yaitu sejumlah Rp. 787.200.000 sehingga terjadi penghematan biaya sebesar Rp. 879.307.000. Tetapi dalam kenyataannya Industri Rumah Panggung Woloan memilih alternatif membeli kayu siap pakai karena dalam mengolah kayu membutuhkan jangka waktu yang cukup lama sehingga tidak memungkinkan untuk pengelolaan kayu untuk kebutuhan sehari-hari dalam pembuatan rumah panggung
\end{abstract}

\title{
Hasil Penelitian Ditinnjau dari Laba Diferensial
}

Laba differensial adalah biaya yang akan datang yang berbeda diantara berbagai macam alternatif yang mungkin dipilih. Besarnya laba differensial dihitung dari perbedaan antara laba pada alternatif tertentu dibandingkan dengan laba pada alternatef lainnya. Besarnya laba differensial dinyatakan dengan rumus : Laba Differensial = Pendapatan Differensial - Biaya Differensial.

Pedoman untuk menentukannya ada tiga macam cara yaitu :

1. Jika alternatif keputusan mempunyai pendapatan differensial dan biaya differensial dan biaya differensial yang berbeda, maka laba differensial adalah sebesar selisih antara pendapatan differensial dengan biaya differensial.

2. Jika pendapatan pada alternatif keputusan besarnya sama, maka laba differensialnya adalah sebesar biaya differensialnya yaitu penghematan biaya antara alternatif yang satu dibandingkan dengan alternatif lainnya.

3. Biaya pada alternatif keputusan besarnya sama, maka laba differensial adalah sebesar pendapatan differensialnya yaitu perbedaan antara pendapatan pada alternatif yang satu dibandingkan dengan pendapatan pada alternatif lainnya.

Dalam pengambilan keputusan membeli atau memproduksi sendiri tersebut informasi akuntansi yang relevan adalah dengan menggunakan laba diferensialnya, yaitu :

Tabel 3. Laporan Laba/Rugi Membeli atau Memproduksi Sendiri Periode 2014

\begin{tabular}{lcrr}
\hline \multicolumn{1}{c}{ Keterangan } & Siap Pakai & Setengah Jadi \\
\hline Penjualan & Rp. 39.360.000.000 & Rp. 39.360.000.000 \\
Biaya Bahan Baku Langsung & & Rp. & 590.400 .000 \\
Biaya Mesin & & Rp. & 71.789 .000
\end{tabular}


Biaya Tenaga Kerja Langsung

Biaya Overhead Pabrik

Harga Beli

(984 x Rp. 800.000)

Total Biaya Diferensial

Penjualan Biaya Diferensial
Rp. $\quad 945.000 .000$

Rp. $\quad 59.318 .000$

Rp. 787.200 .000

Rp. $787.200 .000 \quad$ Rp. 1.666 .507 .000

$\begin{array}{ll}\text { Rp. } 5.314 .800 .000 & \text { Rp. } 3.776 .528 .200\end{array}$

$\begin{array}{ll}\text { Penghematan Biaya } & \text { Rp. 879.307.000 }\end{array}$

Sumber : Hasil Data Olahan 2014

Seluruh penjualan dengan total biaya diferensial yang didapatkan perusahaan jika membeli dari luar adalah Rp 5.314.800.000, sedangkan jika membuat sendiri sebesar Rp. 3.776.528.200, sehingga mendapatkan laba differensial sebesar $\mathrm{Rp}$ 807.518.000.Berdasarkan analisis biaya differensial dapat diputuskan bahwa perusahaan lebih baik membuat sendiri karena mendapatkan selisih laba yang lebih tinggi dibandingkan membeli dari luar yaitu sebesar Rp. 879.307.000.

\section{Pengaruh Biaya Peluang}

Jika Industri Rumah Panggung Woloan membeli kayu yang siap pakai, maka sebagian fasilitas menganggur seperti peralatan mesin, selama menganggur terdapat peluang untuk disewakan kepada pihak lain sebesar Rp. 1.000.000.000.

Dengan asumsi ini berarti akan terjadi biaya peluang sebesar Rp. 1.000.000.000 sehingga biaya untuk memproduksi sendiri menjadi :

Total Biaya produksi sendiri

Biaya Peluang

Rp. 1.666.507.000

Rp. 1.000 .000 .000

Total Biaya diperhitungkan

Rp. $\quad 666.507 .000$

Jika dibandingkan dengan biaya membeli kayu setengah jadi sebesar Rp. 787.200.000 maka memproduksi sendiri menduduki posisi lebih mahal sehingga pada posisi ini keputusan akan beralih menjadi membeli dari luar.

\section{Pembahasan}

Hasil analisis biayadifferensial adalah berbagai perbedaan biaya antara sejumlah alternatif pilihan yang dapat digunakan perusahaan. Analisis biaya differensial digunakan untuk menentukan kenaikan pendapatan, biaya, laba sehubungan dengan beberapa kemungkinan cara untuk menngunakan fasilitas tetap atau kapasitas yang tersedia. Analisis biaya differensial ditujukan untuk mengamati perilaku yang terjadi antara biaya tetap (fixed cost) dengan biaya variabel (variable cost) apabila dikaitkan dengan estimasi kenaikan pendapatan (earning).Jadi konsep dasar dari analisis ini (increasing) adalah untuk mengetahui apakah terjadinya kenaikan pendapatan diiringi kenaikan biaya yang proporsional.Dalam lingkup manajemen analisis ini bisa digunakan dalam pengambilan keputusan membuat sendiri produk atau membeli dari luar. Dan Hasil penelitian dari Dewinta (2014) Melakukan penelitian berjudul Penerapan biaya diferensial dalam pengambilan keputusan membeli atau memproduksi sendiri pada RM. Pangsit Tompaso. Dan hasilnya ,menunjukkan keputusan yang tepat yang dapat diambil manajemen adalah memproduksi sendiri.

\section{PENUTUP}

\section{Kesimpulan}

Dari hasil penelitian dan pembahasan pada bab sebelumnya, maka dapat disimpulkan bahwa : 
1. Hasil penelitian bila ditinjau dari biaya diferensial adalah sebaiknya Industri Rumah Panggung Woloan memilih alternatif membeli kayu setengah jadi dari pada membeli kayu siap pakai karena dengan membeli kayu setengah jadi terjadi penghematan biaya yang cukup besar sehingga bisa lebih menguntungkan usaha Industri Rumah Panggung Woloan

2. Hasil penilitian ditinjau dari laba diferensial adalah sebaiknya Industri Rumah Panggung Woloan membeli kayu setengah jadi karena mendapatkan selisih laba yang tinggi dibandingkan membeli kayu siap pakai agar supaya menguntungkan perusahaan

Terdapat pengaruh biaya peluang yang muncul jika Industri Rumah Panggung Woloan menyewakan peralatan mesin mereka. Jika Industri Rumah Panggung Woloan menyewakan peralatan mesin mereka maka membeli kayu setengah jadi menduduki posisi lebih mahal sehingga pada posisi ini keputusan akan beralih menjadi membeli kayu siap pakai

\section{Saran}

Adapun saran yang penulis dapat berikan sebaagai bahan pertimbangan perusahaan yaitu sebaiknya Industri Rumah Panggung Woloan membeli kayu setengah jadi mengingat biaya yang dikeluarkan lebih rendah dari pada membeli kayu siap pakai karena dapat melakukan penghematan biaya dan juga lebih menguntungkan. Tetapi juga, kalau ada orang yang ingin menyewa peralatan mesin sebaiknya disewakan karena dengan disewakan peralatan mesin maka Industri Rumah Panggung Woloan tidak akan membayar tenaga kerja untuk mengelolah serta merawat mesin atau biaya membeli kayu setengah jadi tidak ada karena dari hasil sewa tersebut Industri Rumah Panggung Woloan bisa membeli kayu siap pakai.

\section{DAFTAR PUSTAKA}

Arfan, ikhsan. 2009, Pengantar Praktis Akuntansi. Edisi Pertama. Graha Ilmu, Yogyakarta.

Darsono Prawironegoro, Purwanti, Ari. 2009. Akuntansi Manajemen. Jilid 1. Edisi ke empat. Erlangga, Jakarta

Horngren, Datar, Foster, George, 2009. Akuntansi Biaya dengan Penekanan Manajerial Jilid 1. Edisi keduabelas.Erlangga. Jakarta

Iqbal, Mohammad, 2013. Pengaruh Biaya Diferensial Terhadap proses pengambilan keputusan manajemen Memproduksi sendiri atau Membeli Produk (Studi pada PT. Fintex).

Krismiaji,Aryani, 2011. Akuntansi Manajemen. UPP STIM YKPN. Yogyakarta Pengambilan Keputusan. Edisi Revisi kelima, Penerbit: Raja Grafindo Persada, Jakarta

Rantung, Dewinta, 2014. Penerapan Biaya Diferensial Dalam Pengambilan Keputusan Membeli atau Memproduksi Sendiri paa RM. Pangsit Tompaso. Jurnal EMBA ISSN 2303-1174 Vol.2 http://ejournal.unsrat.ac.id/index.php/emba/article/viewFile/6067/4585. Diakses 12 Maret 2015. Hal 030-037.

Simamora, Henry. 2012. Akuntansi Manajemen. Edisi III. Star Gate Publisher. Duri, Riau.

Supomo, Bambang. 2012. Akuntansi Manajemen Suatu Sudut Pandan.Penerbit: BPFE, Yogyakarta 
Widilestariningtyas, Ony, Anggraini Sri, Firdaus, Dony. 2012. Akuntansi Biaya. Graha Ilmu. Yogyakarta.

Witjaksono, Armanto, 2006. Akuntansi Biaya. Edisi pertama, cetakan petama. Graha Ilmu.Jogyakarta. 